\title{
Hypsiboas caingua (Carrizo, 1990) (Amphibia: Anura: Hylidae): Geographic distribution with a new state record in Brazil
}

\author{
Gilberto Alves de Souza Filho ${ }^{1^{*}}$ and André Magnani Xavier de Lima ${ }^{2}$
}

\begin{abstract}
1 Hori Consultoria Ambiental. Rua Coronel Temístocles de Souza Brasil, 311. CEP 82520-210. Curitiba, PR, Brazil.
2 Universidade Federal do Paraná. Programa de Pós-Graduação em Ecologia e Conservação. CP 19031. CEP 81531-990. Curitiba, PR, Brazil.

* Corresponding author. E-mail: gilbertoasfilho@yahoo.com.br
\end{abstract}

\begin{abstract}
Hypsiboas caingua (Hylidae) is found in northeastern Argentina, in eastern Paraguay, and in Brazil is known only from the southeastern and southern states of São Paulo and Rio Grande do Sul. In this study we reviewed the geographic distribution of $H$. caingua, including the state of Mato Grosso do Sul, central-western Brazil among the known distribution of the species.
\end{abstract}

The Hypsiboas pulchellus species group comprises 34 recognized taxa (Faivovich et al. 2004, 2005; Antunes et al. 2008; Garcia et al. 2007; Garcia et al. 2008; Kwet 2008) distributed within central and southern South America (Faivovich et al. 2005). Hypsiboas caingua (Carrizo, 1990) was previously found in the Misiones and adjacent Corrientes Provinces in northeastern Argentina (Carrizo 1990; Langone 1993; Lavilla and Cei 2001; Alvarez et al. 2002), in eastern Paraguay (Aquino et al. 1996; Brusquetti and Lavilla 2006), and in the southeastern and southern states of São Paulo (Melo et al. 2007; Condez et al. 2009; Brassaloti et al. 2010; Araujo and Almeida-Santos 2011) and Rio Grande do Sul (Garcia and Vinciprova 1998), Brazil. In Brazil the known distribution of $H$. caingua is within the Atlantic Forest, Cerrado and Pampa biomes.

During a field trip in the municipality of Tacuru, Mato Grosso do Sul State, we found one individual of Hypsiboas caingua in the morning of 23 June 2008. This individual was collected (collection permits SISBio 502-17) and deposited in the herpetological collection of the Museu de História Natural Capão da Imbuia, municipality of Curitiba, Paraná (MHNCI 6594). The identification was achieved following the original description of the species (Carrizo 1990). Like described, the specimen (SVL $=36.5$ $\mathrm{mm}$; Figure 1) presents brown dorsal coloration with three discontinuous longitudinal dark lines; a dark brown dorso-lateral stripe extending from the tip of the snout through eye and tympanum to the flanks, bordered above by a thin whitish stripe; and groin and concealed surfaces of thigh clear with dark spots.

The specimen was resting on a leaf of a caraguatá (Eryngium sp.), in the margin of a river, at a riparian forest

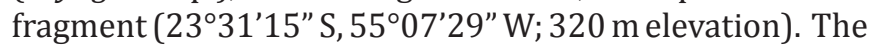
area is characterized by open environment very disturbed, with fragments of riparian semideciduous forest. No other individual of the species was found on site.

This site record extends the geographic distribution of the Hypsiboas caingua to the central-western Brazil, which is located around $500 \mathrm{~km}$ far from the nearest previously reported site in southeastern Brazil (Figure 2). According to the updated geographic extension of $H$. caingua, there is a high probability that the species may also occur in the other southern states of Brazil.

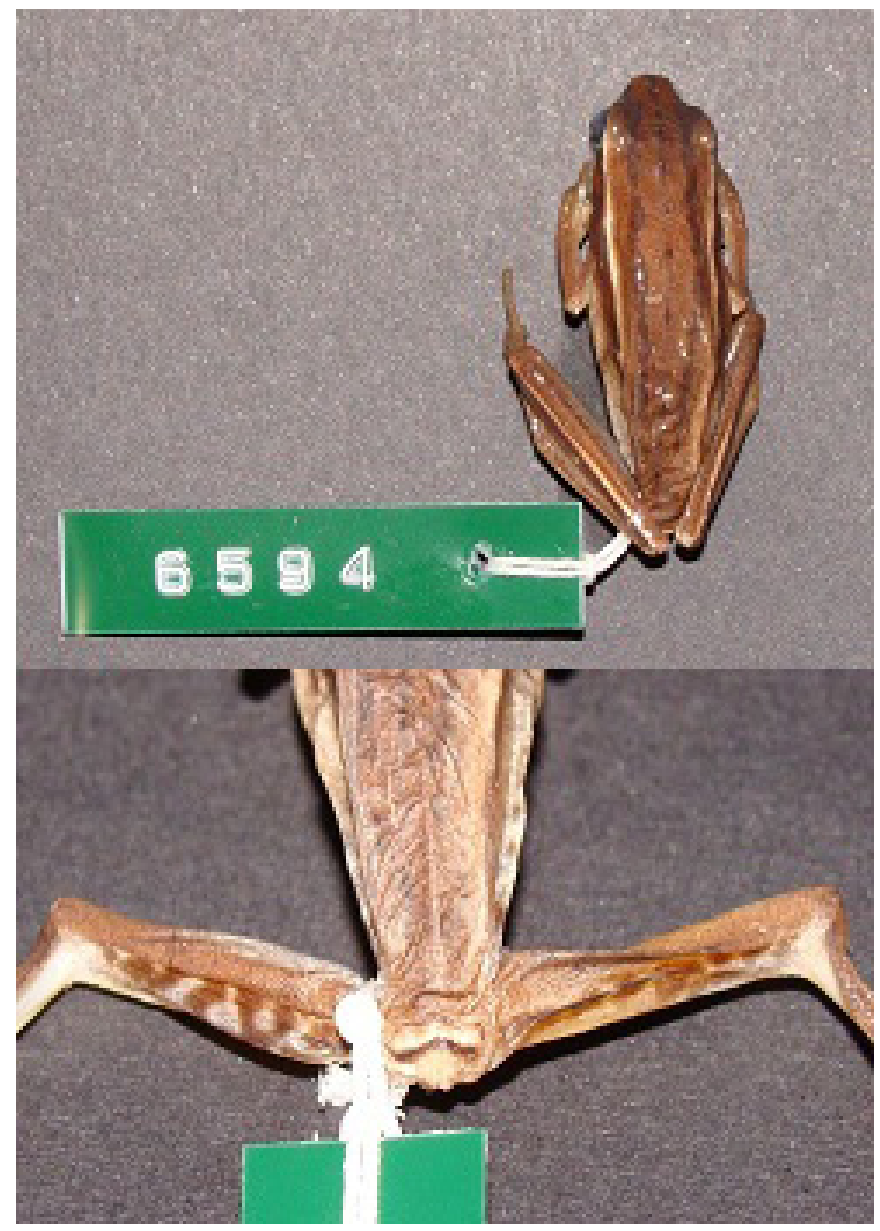

FIGURE 1. Hypsiboas caingua collected in the municipality of Tacuru, state of Mato Grosso do Sul, Brazil (MHNCI 6594). Upper, dorsal view; below, detail of the concealed surfaces of thigh. 


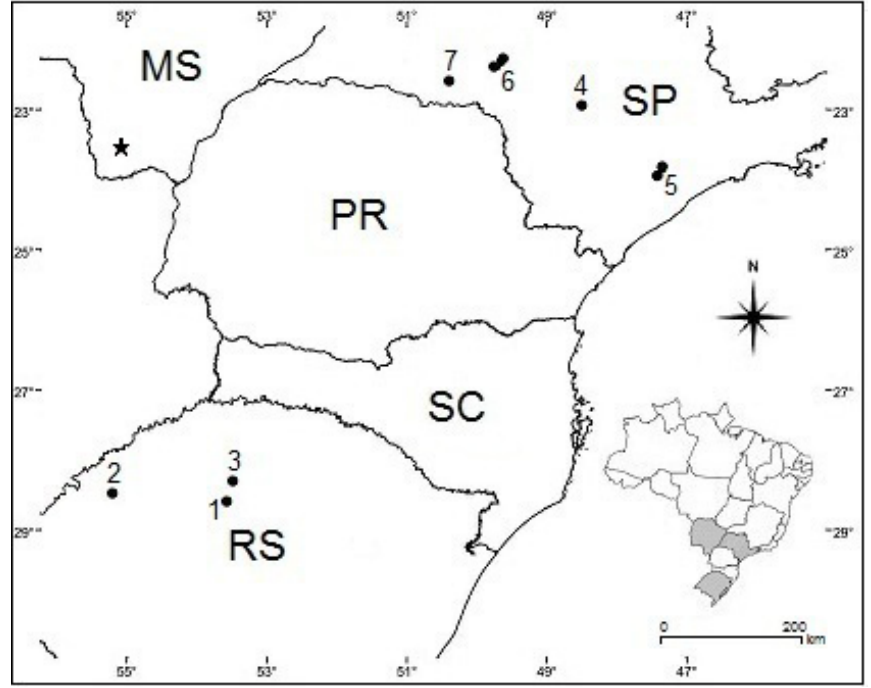

FIGURE 2. Distribution map of Hypsiboas caingua in Brazil: 1. Cruz Alta, 2. Santo Antônio das Missões, 3. Panambi (Condor), at Rio Grande do Sul State (RS); 4. Botucatu (Rubião Júnior), 5. Tapiraí and Piedade, 6. Alvinlândia and Gália (Estação Ecológica dos Caetetus), 7. Assis (Estação Ecológica de Assis), at São Paulo State (SP). The star indicates the new occurrence in the municipality of Tacuru, Mato Grosso do Sul State (MS). Data from: 1, 2, 3. Garcia and Vinciprova (1998); 4. Melo et al. (2007); 5. Condez et al. (2009); 6. Brassaloti et al. (2010); 7. Araujo and AlmeidaSantos (2011).

ACKNowledgments: We thank to Instituto de Pesquisa e Conservação da Natureza Idéia Ambiental for opportunity and logistic support in the field.

\section{LITERATURE Cited}

Alvarez, B.B., R.H. Aguirre, J.A. Céspedez, A.B. Hernando and M.E. Tedesco. 2002. Atlas de Anfíbios y Reptiles de las provincias de Corrientes, Chaco y Formosa (Argentina). Corrientes: Editorial Universitaria de la Universidad Nacional del Nordeste. 156 p.

Antunes, A.P., J. Faivovich and C.F.B. Haddad. 2008. A new species of Hypsiboas from the Atlantic Forest of Southeastern Brazil (Amphibia, Anura, Hylidae). Copeia 2008(1): 177-188.

Aquino, A.L., N.J. Scott and M. Motte. 1996. Lista de anfíbios y reptiles del Museo de Historia Natural del Paraguay (Marzo, 1980 - Septiembre, 1995); p. 331-400 In O.R. Romero (ed.). Coleccion de Flora y Fauna del Museo Nacional de Historia Natural del Paraguay. Asuncion: Museo Nacional de Historia Natural del Paraguay.
Araujo, C.O. and S.M. Almeida-Santos. 2011. Herpetofauna de um remanescente de cerrado no estado de São Paulo, sudeste do Brasil. Biota Neotropica 11(3): 1-16.

Brassaloti, R.A., D.C. Rossa-Feres and J. Bertoluci. 2010. Anurofauna da Floresta Estacional Semidecidual da Estação Ecológica dos Caetetus, Sudeste do Brasil. Biota Neotropica 10(1): 275-292.

Brusquetti, F. and E.O. Lavilla. 2006. Lista comentada de los anfibios de Paraguay. Cuadernos de Herpetología 20(2): 3-79.

Carrizo, G. 1990. Sobre los hilidos de Misiones, Argentina, con la descripción de una nueva especie, Hyla caingua n. sp. (Anura, Hylidae). Cuadernos de Herpetología 5(6): 32-39.

Condez, T.H., R.J. Sawaya and M. Dixo. 2009. Herpetofauna dos remanescentes de Mata Atlântica da região de Tapiraí e Piedade, SP, sudeste do Brasil. Biota Neotropica 9(1): 157-185.

Faivovich, J., P.C.A. Garcia, F. Ananias, L. Lanari, N.G. Basso and W.C. Wheeler. 2004. A molecular perspective on the phylogeny of the Hyla pulchella species group (Anura, Hylidae). Molecular Phylogenetics and Evolution 32: 938-950.

Faivovich, J., C.F.B. Haddad, P.C.A. Garcia, D.R. Frost, J.A. Campbell and W.C. Wheeler. 2005. Systematic review of the frog family Hylidae, with special reference to Hylinae: phylogenetic analysis and taxonomic revision. Bulletin of the American Museum of Natural History 294: 1-240.

Garcia, P.C.A. \& G. Vinciprova. 1998. Range extensions of some anuran species for Santa Catarina and Rio Grande do Sul states, Brazil. Herpetological Review 29(2): 117-118.

Garcia, P.C.A., J. Faivovich and C.F.B. Haddad. 2007. Redescription of Hypsiboas semiguttatus (A. Lutz, 1925), with the description of a new species of the Hypsiboas pulchellus group. Copeia 2007(4): 933-951.

Garcia, P.C.A., O.L. Peixoto and C.F.B. Haddad. 2008. A new species of Hypsiboas (Anura: Hylidae) from the Atlantic Forest of Santa Catarina, Southern Brazil, with comments on its conservation status. South American Journal of Herpetology 3(1): 27-35.

Kwet, A. 2008. New species of Hypsiboas (Anura: Hylidae) in the pulchellus group from southern Brazil. Salamandra 44: 1-14.

Langone, J.A. 1993. Ampliación de la distribución geográfica de Hyla caingua Carrizo, 1990 (Amphibia, Anura, Hylidae). Boletín de la Asociación Herpetológica Argentina 9: 8.

Lavilla, E.O. and J.M. Cei. 2001. Amphibians of Argentina. A second update, 1987-2000. Monografie dei Museo Regionale di Scienze Naturali di Torino 28: 1-78.

Melo, G.V., D.C. Rossa-Feres and J. Jim. 2007. Variação temporal no sítio de vocalização em uma comunidade de anuros de Botucatu, Estado de São Paulo, Brasil. Biota Neotropica 7(2): 93-102.

RECEIVED: January 2012

ACCEPTED: July 2012

PUBLISHED ONLINE: August 2012

EDITORIAL RESPONSIBILITY: Marcelo Nogueira de Carvalho Kokubum 